\title{
Evaluating extreme flood characteristics of small mountainous basins of the Black Sea coastal area, Northern Caucasus
}

\author{
L. S. Lebedeva ${ }^{1}$, O. M. Semenova ${ }^{2,3}$, T. A. Vinogradova ${ }^{3}$, M. N. Kruchin ${ }^{4}$, and N. V. Volkova ${ }^{5}$ \\ ${ }^{1}$ Melnikov Permafrost Institute, Yakutsk, Russia \\ ${ }^{2}$ Gidrotehproekt Ltd., St. Petersburg, Russia \\ ${ }^{3}$ St. Petersburg State University, St. Petersburg, Russia \\ ${ }^{4}$ ANO Training and Consulting Center "Izyskatel", Moscow, Russia \\ ${ }^{5}$ State Hydrological Institute, St. Petersburg, Russia \\ Correspondence to: L. S. Lebedeva (lyudmilaslebedeva@gmail.com)
}

Received: 11 March 2015 - Accepted: 11 March 2015 - Published: 11 June 2015

\begin{abstract}
The probability of heavy rains and river floods is expected to increase with time in the Northern Caucasus region. Densely populated areas in the valleys of small mountainous watersheds already frequently suffer from catastrophic peak floods caused by intense rains at higher elevations. This study aimed at assessing the flood characteristics of several small basins in the piedmont area of the Caucasus Mountains adjacent to the Black Sea coast including ungauged Cemes River in the Novorossiysk city. The Deterministic-Stochastic Modelling System which consists of hydrological model Hydrograph and stochastic weather generator was applied to evaluate extreme rainfall and runoff characteristics of $1 \%$ exceedance probability. Rainfall intensity is shown to play more significant role than its depth in formation of extreme flows within the studied region.
\end{abstract}

\section{Introduction}

The probability of heavy rains and river floods has been increasing recently and is expected to increase in the future in the Caucasus region (Semenov, 2011; Tkachenko and Volosukhin, 2013). High population density, intensive land use, highly developed industry, numerous infrastructure and recreation facilities amplify the risks of material losses and casualties due to extreme floods on the rivers in Northern Caucasus.

This study aimed at assessing extreme rainfall and flood characteristics at several small watersheds, located at the Black Sea coast in the piedmont area of the Caucasus Mountains including ungauged Cemes River in Novorossiysk city by the means of hydrological modelling combined with stochastic weather generator.

\section{The study objects}

Five watersheds in North-Western part of Caucasus Mountains with basin areas from 53.7 to $352 \mathrm{~km}^{2}$ were studied (Fig. 1, Table 1). Daily discharge records are available for four basins while the Cemes River watershed is ungauged.

Mean altitude of the watersheds changes gradually from $200 \mathrm{~m}$ (maximum $531 \mathrm{~m}$ ) at the Durso River basin to $365 \mathrm{~m}$ (maximum $1374 \mathrm{~m}$ ) at the Tuapse River basin. The climate is moist subtropical. There is a significant increase in runoff (from 300 to $1150 \mathrm{~mm} \mathrm{yr}^{-1}$ ), precipitation (from 740 to $1750 \mathrm{~mm} \mathrm{yr}^{-1}$ ) and evapotranspiration (from 440 to $600 \mathrm{~mm} \mathrm{yr}^{-1}$ ) from north-west to south-east of the coast all of the latter following the elevation rise (Fig. 1). The watersheds are covered by oak, pine and hornbeam forests, with urban areas present in the river valleys. They stay below snow line and the runoff is mainly generated by rainstorms. Most of them are observed from November to March. The floods can be also formed by tornadoes. 
Table 1. Main characteristics of studied basins.

\begin{tabular}{lccrcc}
\hline River & $\begin{array}{r}\text { Length } \\
\text { of river, } \\
\mathrm{km}\end{array}$ & $\begin{array}{c}\text { Basin } \\
\text { area, } \\
\mathrm{km}^{2}\end{array}$ & $\begin{array}{r}\text { Weighted } \\
\text { average } \\
\text { slope, } \\
\% 0\end{array}$ & $\begin{array}{c}\text { Average } \\
\text { slope, } \\
\% 0\end{array}$ & $\begin{array}{c}\text { Average } \\
\text { altitude, } \mathrm{m}\end{array}$ \\
\hline Durso & 14 & 53.7 & 12,5 & 241 & 190 \\
Cemes & 14 & 82.6 & 10.6 & 179 & 150 \\
Adebra & 20 & 73.5 & 14.3 & 279 & 340 \\
Vulan & 29 & 278 & 6.3 & 272 & 240 \\
Tuapse & 35 & 352 & 16.5 & & 335 \\
\hline
\end{tabular}

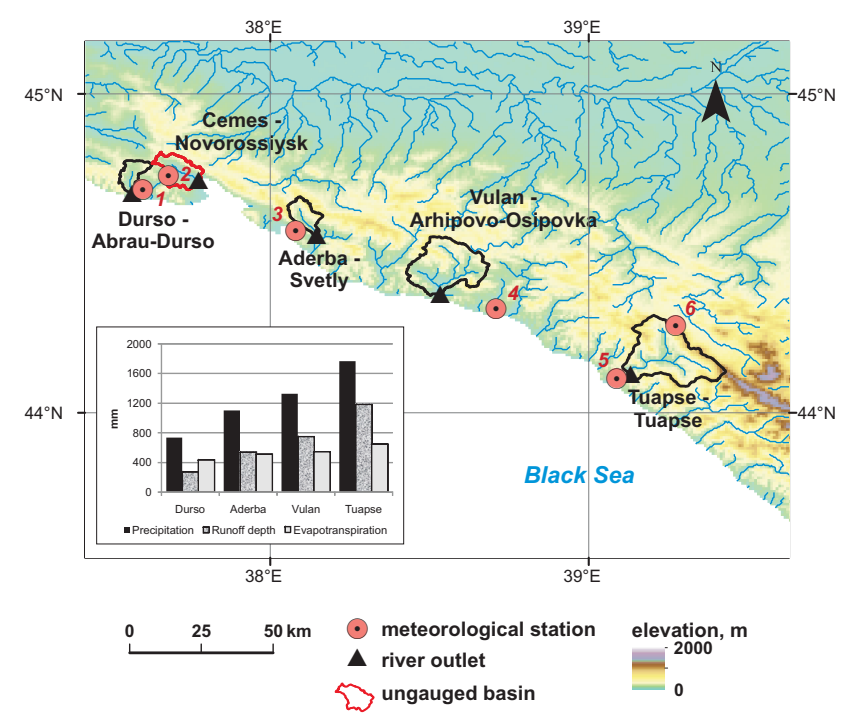

Figure 1. The scheme showing studied basins, meteorological stations (1 - Abrau-Durso, 2 - Novorossiysk, 3 - Gelendshik, 4 Dzhubga, 5 - Tuapse, 6 - Gorny) and mean annual runoff, precipitation and evapotranspiration $(\mathrm{mm})$ for each gauged basin.

\section{The deterministic-stochastic modelling approach}

The lack of runoff gauges and highly variable meteorological and landscape conditions of the Northern Caucasus foothills, when the amount of precipitation increases more than twice within $175 \mathrm{~km}$ distance, make unreliable the standard engineering approaches (SP-33-101-2003, 2004; Rogger et al., 2012) based on selection and use of analogous basins and extrapolation of observed values to low probabilities. In our study, we use deterministic-stochastic (DS) modelling approach which implies joint application of deterministic hydrological model and stochastic weather model (SWM).

Distributed hydrological model Hydrograph (Vinogradov, 1988; Vinogradov et al., 2011) describes runoff formation processes at a watershed in different landscape and climate zones based on physical principles. Daily values of air temperature and humidity, precipitation sum and duration are used as meteorological input. The model outputs are the continuous runoff hydrographs at the outlet and the spatially dis-

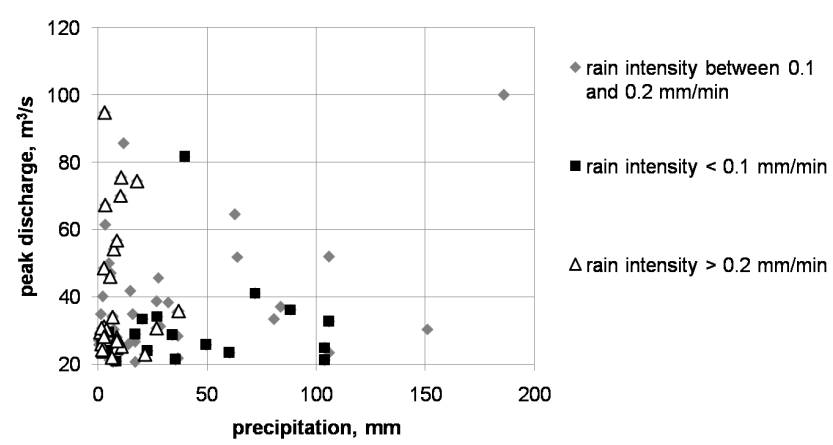

Figure 2. Peak discharge-precipitation relationship for different rain intensities ranges, Tuapse River, meteorological station Tuapse, 1974-1990.

tributed variable states of soil and snow cover in the basin. The model is run on a daily time step.

The stochastic weather model (SWM) provides a meteorological input for the deterministic hydrological model. Daily air temperature and humidity, precipitation depth are generated by SWM taking into account its temporal and spatial correlation between the gauging stations. The parameters of SMW are evaluated based on observed series of daily meteorological information. The idea behind using the SWM is to prolong meteorological data series with given statistical parameters to assess extreme values of meteorological variables that were not observed during historical period.

\section{Deterministic-stochastic hydrological modelling}

\subsection{Deterministic hydrological modelling}

The Hydrograph model was firstly applied and validated on four gauged basins and then the refined model parameters were transferred to the ungauged Cemes River basin. Continuous modelling periods range from 11 to 30 years within 1966-1995 depending on hydrometeorological data availability for each watershed.

The basins were presented by two conditionally homogeneous land surface types in the model, oak forest and urban land (Bitukov, 2007). In the sense of the model parameterization, main difference between them is a lower permeability of the surface soil layer and less evaporation in the urban land. For the adjustment of precipitation input in mountainous relief local relationships between precipitation amount and elevation were elaborated. Daily precipitation data interpolated from meteorological stations were adjusted according to those relationships and the altitude of each grid cell.

First modelling results revealed that while the general agreement between observed and simulated daily discharges and water balance components is satisfactory, extreme peakfloods are significantly underestimated (Fig. 3, Table 2). The main reason is an absence of rain duration data and a lack of reliable meteorological input in mountainous conditions 
Table 2. Observed and simulated annual values of water balance (mm) and Nash-Sutcliffe efficiency.

\begin{tabular}{lrrrcr}
\hline River & $\begin{array}{r}\text { Simulated } \\
\text { flow }\end{array}$ & $\begin{array}{r}\text { Observed } \\
\text { flow }\end{array}$ & $\begin{array}{r}\text { Estimated } \\
\text { precipitation }\end{array}$ & $\begin{array}{r}\text { Simulated } \\
\text { evapotranspiration }\end{array}$ & $\begin{array}{r}\text { Nash-Sutcliffe } \\
\text { efficiency }\end{array}$ \\
\hline Tuapse & 1115 & 1183 & 1766 & 651 & 0.56 \\
Durso & 292 & 272 & 735 & 437 & -0.67 \\
Aderba & 583 & 543 & 1099 & 511 & -0.04 \\
Vulan & 782 & 752 & 1325 & 544 & 0.30 \\
Cemes & 382 & - & 848 & 470 & - \\
\hline
\end{tabular}
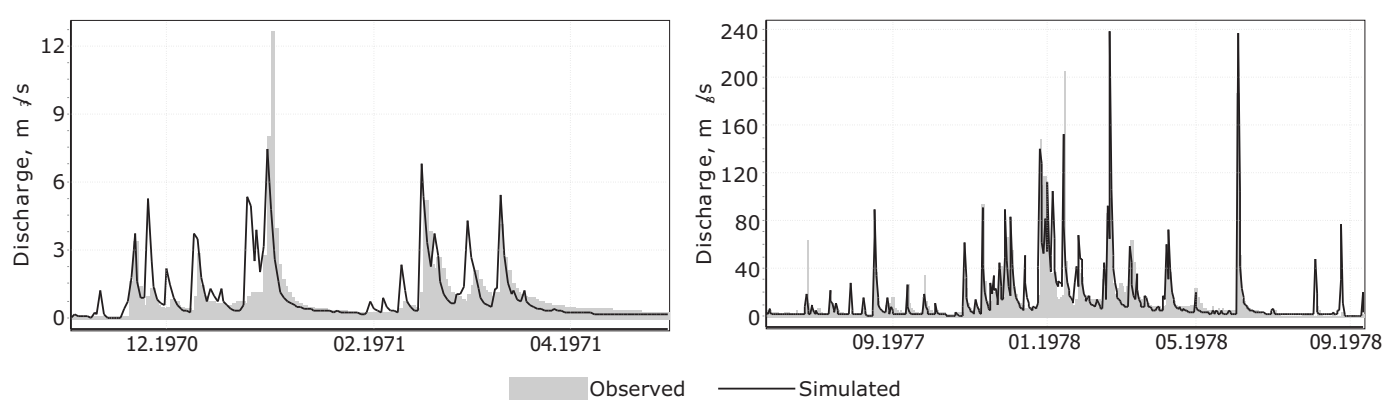

Figure 3. Simulated and observed hydrographs at the Durso River basin (left panel, 1970-1971) and the Tuapse River basin (right panel, 1977-1978).

when the precipitation observed at a meteorological station is not representative even for a neighboring river valley. Such Nash-Sutcliffe efficiency is satisfactory for the Tuapse River basin (0.56) as it has two meteorological stations within the basin, has negative values for the Durso and Aderba Rivers and 0.30 for the Vulan River.

To understand and improve modelling performance in simulating extreme floods, the analysis of event-based mean and maximum precipitation intensities and amounts for rainfall larger than $10 \mathrm{~mm} \mathrm{day}^{-1}$ was performed. Maximum daily precipitation depth and its corresponding mean and maximum intensity at Novorossiysk, Gorny and Tuapse are presented in Table 3. Figure 2 shows the dependence of peak discharges on precipitation for the Tuapse River. One can notice that moderate precipitation (up to $30 \mathrm{~mm} \mathrm{day}^{-1}$ ) with higher intensities (more $0.2 \mathrm{~mm} \mathrm{~min}^{-1}$ ) generally form considerably larger floods than higher precipitation (30$120 \mathrm{~mm} \mathrm{day}^{-1}$ ) with lower intensities (less $0.1 \mathrm{~mm} \mathrm{~min}^{-1}$ ). Observed patterns of rain intensity in studied region have significant variability and could not be fitted by analytic expression with constant parameters $T=a H^{b}$, where $T$ - rain duration (min), $H$ - precipitation (mm), $a$ - parameter of rain duration $\left(\mathrm{min} \mathrm{mm}^{-1}\right), b$-nonlinear parameter, that is used in the Hydrograph model in the absence of rain duration input data with standard parameters $a=50, b=0.84$.

Simulation experiments with different values of the parameters of rain duration revealed that maximum flows of low probability are generated by the rainstorms of very high average intensity (up to $1 \mathrm{~mm} \mathrm{~min}^{-1}$ ). The mean values of the parameters affecting the calculation of the intensity of precipitation, used in the Hydrograph model, do not meet the hydrometeorological conditions of formation of high floods. For an adequate simulation of flows of low probability such values of the model parameters were set up to provide about $0.5-0.6 \mathrm{~mm} \mathrm{~min}^{-1}$. The comparison of observed and simulated with different sets of the model parameters maximum flows are depicted at probability curves at Fig. 4.

In the ungauged Cemes River basin the deterministic modelling was performed for the period 1966-1983 with daily time step with the values of the model parameters assessed on gauged basins. Adjusted parameters of rain duration were applied as well to simulate high flows. Estimated average values of annual water balance are the following: flow $-380 \mathrm{~mm}$, precipitation $-850 \mathrm{~mm}$, evapotranspiration $-470 \mathrm{~mm}$. Runoff coefficient reached up the value 0.45 (Table 2).

\subsection{Results of deterministic-stochastic modelling}

Continuous daily series of precipitation, air temperature and humidity for a period of 100 years were simulated using SMW for each basin according to the parameters evaluated on the basis of observations at meteorological stations. Simulated meteorological series were used as the input to calculate the maximum flood of $1 \%$ probability in the studied basins. Following the aim to get high flows right we used the set of the model parameters which provided maximum intensity of precipitation. For ungauged Cemec River the extreme values ( $1 \%$ exceeding probability) of flow and precipitation were estimated as follows: maximum discharge was 
Table 3. Maximum daily rain depth and corresponding mean and maximum intensity at meteorological stations.

\begin{tabular}{lrcccl}
\hline $\begin{array}{l}\text { Meteorological } \\
\text { station }\end{array}$ & $\begin{array}{r}\text { Elevation, } \\
\mathrm{m}\end{array}$ & $\begin{array}{c}\text { Period of } \\
\text { data }\end{array}$ & $\begin{array}{c}\text { Maximum } \\
\text { precipitation } \\
\text { per day, mm }\end{array}$ & $\begin{array}{c}\text { Mean } \\
\text { intensity, } \\
\mathrm{mm} \mathrm{min}^{-1}\end{array}$ & $\begin{array}{l}\text { Maximum } \\
\text { intensity, } \\
\mathrm{mm} \mathrm{min}^{-1}\end{array}$ \\
\hline Novorossiysk & 7 & $\begin{array}{r}1974-1990, \\
1997-2011\end{array}$ & 178 & 0.65 & 2.12 \\
\hline Tuapse & 41 & $\begin{array}{r}1974-1990, \\
1997-2011\end{array}$ & 124 & 0.24 & 3.14 \\
\hline Gorny & 324 & $1997-2011$ & 291 & 0.36 & 1.9 \\
\hline
\end{tabular}

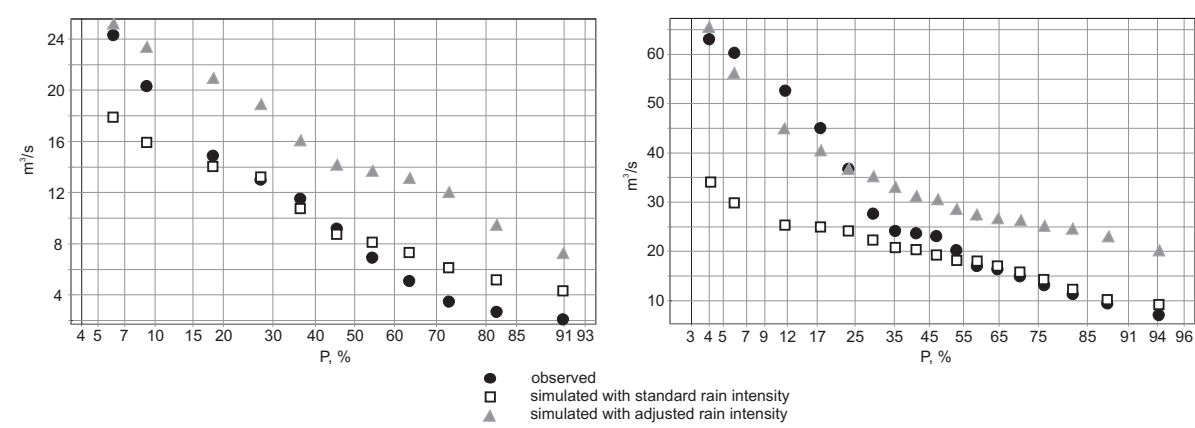

Figure 4. The probability curves of annual maximum floods simulated with standard and adjusted parameters of rain intensity, the Durso River (left panel) and the Aderba River (right panel).

$80 \mathrm{~m}^{3} \mathrm{~s}^{-1}$, maximum daily precipitation $-210 \mathrm{~mm}$, maximum daily flow depth $-84 \mathrm{~mm}$.

\section{Conclusions}

Hydrological modelling was conducted for five mountainous basins at the Black Sea coast, including one ungauged basin.

It was revealed that extreme floods in the basins of the North Caucasus Black Sea coast are generated by strong rainfall storms with very high intensity. Rainfall intensity plays more significant role than its depth in causing extreme runoff events. For better flow simulation results, observed or estimated data on rainfall duration and intensity are required hence hourly time step of calculations would be more appropriate for studied basins due their small size and steepness. The application of empirical depth (intensity)-durationfrequency curves (Van Dijk et al., 2005) would be helpful in this study but is not possible because it needs to be validated against observed long-term precipitation data on high temporal resolution. Hourly rain intensities, duration and depth are not easy to obtain in Russia.

Catastrophic rains leading to the formation of extreme floods are very local, and the synchronicity of the formation of a particularly high peak flow in adjacent watersheds and even at different gauges of one river often cannot be traced. This may cause inadequate calculation of maximum flows in ungauged basins based on the use of basin-analogues. The scarcity of meteorological stations in the studied region is also a reason for poor modelling results for individual flow events at most studied rivers. In this case the application of DS-modelling approach allows for the assessment of general flood characteristics of different probabilities in ungauged basins providing the possibility to account for the factors causing extreme runoff events which were not observed before or projected for future.

Acknowledgements. We thank Nikita Tananaev for his help with the English language.

\section{References}

Bitukov, N. A.: Ecology of mountainous forests of Black Sea region, SIMBiP, FGU "NIIgorkesecol”, Sochi, 1-292, 2007.

Rogger, M., Kohl, B., Pirkl, H., Viglione, A., Komma, J., Kirnbauer, R., Merz, R., and Blöschl, G.: Runoff models and flood frequency statistics for design flood estimation in Austria - Do they tell a consistent story?, J. Hydrol., 456-457, 30-43, 2012.

Semenov, V. A.: Climate-related changes in hazardous and adverse hydrological events in the Russian rivers, Russ. Meteorol. Hydrol., 36, 124-129, 2011.

SP-33-101-2003: Determination of design hydrological performance, Russian Federation Gosstroy, Moscow, 2004.

Tkachenko, Y. Y. and Volosuhin, V. A.: Forecasting of floods parameters on the Krasnodar region rivers, Hydrotechnics, 4, 1620, 2013. 
Van Dijk, A. I. J. M., Meesters, A. G. C. A., Schellekens, J., and Bruijnzeel, L. A.: A two-parameter exponential rainfall depthintensity distribution applied to runoff and erosion modelling, J. Hydrol., 300, 155-171, 2005.

Vinogradov, Y. B.: The mathematical modeling of runoff formation processes. The experience in critical analysis, Gidrometeoizdat, Leningrad, 1-312, 1988.
Vinogradov, Y. B., Semenova, O. M., and Vinogradova, T .A.: An approach to the scaling problem in hydrological modelling: the deterministic modelling hydrological system, Hydrol. Process., 25, 1055-1073, doi:10.1002/hyp.7901, 2011. 